\title{
Penggunaan Pestisida Biorasional untuk Pengendalian Penyakit Hawar Daun Bakteri pada Tanaman Padi
}

\author{
The Use of Biorational Pesticides for Bacterial Leaf Blight Control on Rice Plants
}

\author{
Agus Nurawan $^{1}$, Yati Haryati ${ }^{2}$, Kiki Kusyaeri Hamdani ${ }^{3}$
}

${ }^{1,2,3}$ Balai Penelitian Teknologi Pertanian, Jawa Barat, Indonesia

\section{ARTICLE INFO \\ Article history: \\ DOI: \\ $\underline{10.30595 / p s p f s . v 2 i .187}$}

Submitted:

July 29, 2021

Accepted:

Sept 10, 2021

Published:

Nov 10, 2021

Keywords:

$\mathrm{R} / \mathrm{C}$ ratio, Rice, Sintanur

\begin{abstract}
Bacterial leaf blight can cause rice loss between 15-80\%. Biorational pesticides can be an alternative to controlling the disease. Bacillus firmus, Burkholderia sp, and Serratia marcescens against bacterial leaf blight on rice plants in the field. The study was conducted in Maret-Juni 2014 in the land of the Independent Farmers Group, Cipeuyeum Village, Haurwangi District, Cianjur Regency, West Java. The design uses a randomized complete block design (RCBD) with 6 treatments and 4 replications. The treatments consist of: 1) Mekongga + biorational, 2) Inpari $14+$ biorational, 3) Sintanur + biorasional, 4) Mekongga + without biorational, 5) Inpari 14 + without biorational, and 6) Sintanur + without biorational. The results of the study showed that the application of biorational pesticides can reduce the intensity of bacterial leaf blight disease. Sintanur varieties with the application of biorational pesticides produce higher and higher $\mathrm{R} / \mathrm{C}$ ratios of 6.81 tons ha-1 and 2.79.
\end{abstract}

This work is licensed under a Creative Commons Attribution 4.0 International License.

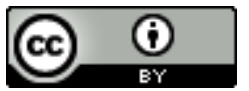

Corresponding Author:

Kiki Kusyaeri Hamdani

Balai Penelitian Teknologi Pertanian, Jawa Barat, Indonesia

Email: kusyaeri_fuji@yahoo.co.id

\section{PENDAHULUAN}

Serangan hama dan penyakit merupakan salah satu faktor pembatas dalam budidaya padi karena menyebabkan kerusakan pada tanaman. Salah satu penyakit yang sering merugikan petani adalah hawar daun bakteri (HDB). Penyakit yang disebabkan oleh bakteri Xanthomonas oryzae pv. oryzae tersebut merupakan salah satu penyakit utama padi yang sudah tersebar pada berbagai ekosistem padi khususnya di negara-negara penghasil padi, termasuk di Indonesia. Serangannya bisa terjadi mulai dari pesemaian sampai menjelang panen dengan cara menginfeksi bagian daun tanaman padi melalui luka daun atau lubang alami berupa stomata dan merusak klorofil daun sehingga kemampuan tanaman untuk berfotosintesis menurun. Jika menyerang tanaman muda akan mengakibatkan layu dan mati sedangkan pada saat fase generatif menyebabkan kurang sempurnanya pengisian gabah (Sudir dkk., 2012). Kerugian yang ditimbulkan oleh serangan HDB di daerah tropis lebih tinggi dibandingkan di daerah subtropik karena banyaknya strain patogen yang ditemukan akibat karakter iklim tropis tersebut (Wahyudi dkk., 2011).

Sampai saat ini berbagai upaya telah dilakukan untuk mengendalikan penyakit HDB yaitu dengan menggunakan bahan kimia atau pestisida sintetik yang berpotensi menyebabkan resistensi terhadap bakteri, menimbulkan residu, dan pencemaran lingkungan. Menurut Wahyudi dkk., (2011) upaya pengendalian HDB terkendala oleh kemampuan patogen membentuk strain baru yang lebih virulen lebih cepat sedangkan penggunaan pestisida kimia dapat menyebabkan gangguan pada kesehatan manusia dan lingkungan. 
Untuk mengatasi hal tersebut, berbagai cara pengendalian mulai dikembangkan diantaranya melalui penggunaan pestisida biorasional. Pestisida biorasional merupakan pestisida yang bahan aktifnya berasal dari alam yang tidak memiliki atau sangat minim pengaruhnya terhadap manusia, lingkungan, dan organisme bermanfaat. Penggunaan pestisida biorasional yang mengandung mikroba seperti bakteri menjadi alternatif yang tepat karena tidak mencemari lingkungan. Bakteri-bakteri tersebut menghasilkan senyawa metabolit yang mempunyai efek bakterisidal untuk menghambat pertumbuhan bakteri patogen. Menurut Putra dan Giyanto (2014) pengendalian mulai beralih dengan memanfaatkan sumber daya biologi untuk meningkatkan kesehatan dan ketahanan tanaman terhadap penyakit diantaranya melalui peran mikrob tanah yang bermanfaat. Hasil penelitian Zuraidah (2013) menunjukkan bahwa Bacillus sp. merupakan salah satu jenis mikroba yang berpotensi dalam menghambat pertumbuhan bakteri patogen tanaman padi X. oryzae pv. oryzae secara in vivo dibandingkan menggunakan akuades steril dan tembaga sulfat sebagai bakterisida kimia. Penelitian Agustiansyah dkk., (2013) menunjukkan bahwa B. subtilis mempunyai kemampuan menghambat pertumbuhan X. oryzae pv. oryzae. Khoa dkk., (2016) melaporkan bahwa Serratia nematodiphila menunjukkan potensinya sebagai pengendali penyakit hawar daun bakteri di sawah.

Tujuan dari penelitian ini adalah untuk mengetahui pengaruh pestisida biorasional yang mengandung Bacillus firmus, Burkholderia sp., dan Serratia marcescens terhadap penyakit hawar daun bakteri pada tanaman padi.

\section{METODE PENELITIAN}

\section{Waktu dan Lokasi}

Penelitian dilaksanakan pada bulan Maret sampai dengan Juni 2014. Lokasi penelitian dilakukan di lahan sawah Kelompok Tani Mandiri, Desa Cipeuyeum, Kecamatan Cipeuyeum, Kabupaten Cianjur. Kecamatan Cipeuyeum merupakan daerah endemik penyakit HDB.

\section{Bahan}

Bahan yang digunakan terdiri dari benih padi varietas Mekongga, Inpari 14, Sintanur yang diperoleh dari BB Padi (Sukamandi, Indonesia) dan pestisida biorasional yang berasal dari BB Biogen (Bogor, Indonesia).

\section{Alat}

Alat-alat yang digunakan terdiri dari sprayer dan caplak.

\section{Rancangan Percobaan}

Rancangan percobaan yang digunakan yaitu Rancangan Acak Kelompok Lengkap (RAKL) dengan 6 perlakuan dan 4 ulangan.

Perlakuan terdiri dari:

$1=$ Mekongga + biorasional

$2=$ Mekongga + tanpa biorasional

$3=$ Inpari $14+$ biorasional

$4=$ Inpari $14+$ tanpa biorasional

$5=$ Sintanur + biorasional

$6=$ Sintanur + tanpa biorasional

Pestisida biorasional yang diaplikasikan pada penelitian ini mengandung Bacillus firmus, Burkholderia, dan Serratia marcescens. Waktu aplikasi dilakukan pada umur 14, 28 dan 42 HST dengan dosis 2 g/lt air.

Peubah yang diamati terdiri dari tinggi tanaman, jumlah anakan, produktivitas, intensitas serangan penyakit HDB, dan residu pestisida pada beras.

Pengamatan tingkat serangan HDB dilakukan pada fase generatif dengan mengacu pada IRRI (2013) yaitu pada skala $0-9$ (skor $0=$ tidak ada luka; $1=1-5 \%, 3=6-12 \%, 5=13-25 \%, 7=26-50 \%$, dan $9=51$ $100 \%)$

Tingkat intensitas serangan HDB dihitung dengan rumus :

$\mathrm{I}=\sum \mathrm{n} . \mathrm{v} / \mathrm{V} \times \mathrm{N} \times 100 \%$

Keterangan :

$\mathrm{I}=$ tingkat kerusakan tanaman

$\mathrm{n}=$ jumlah skala tiap kategori serangan

$\mathrm{v}=$ nilai skala hasil pengamatan tertentu

$\mathrm{V}=$ nilai skala tiap kategori serangan tertinggi

$\mathrm{N}=$ jumlah tanaman contoh yang diamati 
Analisis residu beras menggunakan gas chromatography-electron capture detector (GC-ECD).

Data agronomis dianalisis dengan sidik ragam. Jika berpengaruh nyata diuji lanjut dengan uji Duncan Multiple Range Test (DMRT) pada taraf 5\%. Selain itu dilakukan analisis usahatani yaitu dengan menggunakan R/C rasio.

\section{HASIL DAN PEMBAHASAN}

\section{Tinggi tanaman dan jumlah anakan}

Rata-rata tinggi tanaman padi umur 14, 28, dan 42 HST pada berbagai kombinasi perlakuan lebih dipengaruhi oleh varietas padi, walaupun pada umur 56 HST menghasilkan tinggi tanaman yang sama. Jumlah anakan yang dihasilkan tidak dipengaruhi oleh perlakuan kecuali pada umur 28 HST dimana perlakuan varietas Inpari 14 tanpa aplikasi pestisida biorasional menghasilkan jumlah anakan yang lebih sedikit (Tabel 1). Pengaruh dari karakteristik pertumbuhan seperti tinggi tanaman dan jumlah anakan yang dipengaruhi oleh gen dari masing-masing varietas terlihat lebih dominan. Hasil penelitian Nurawan dan Sunandar (2015) menunjukkan tidak adanya pengaruh aplikasi biorasional terhadap jumlah anakan padi.

Tabel 1. Rata-rata Tinggi Tanaman dan Jumlah Anakan Padi

\begin{tabular}{|c|c|c|c|c|c|c|}
\hline \multirow{2}{*}{ Perlakuan } & \multicolumn{4}{|c|}{ Tinggi tanaman $(\mathrm{cm})$} & \multicolumn{2}{|c|}{ Jumlah anakan (anakan) } \\
\hline & $14 \mathrm{HST}$ & $28 \mathrm{HST}$ & 42 HST & 56 HST & $14 \mathrm{HST} 28 \mathrm{HST}$ & $42 \mathrm{HST} 56 \mathrm{HST}$ \\
\hline Mekongga+ biorasional & $45,60 \mathrm{a}$ & $59,70 \mathrm{a}$ & $68,35 \mathrm{bc}$ & $70,30 \mathrm{a}$ & $17,25 \mathrm{a} 26,15 \mathrm{ab}$ & $26,20 \mathrm{a} 26,50 \mathrm{a}$ \\
\hline $\begin{array}{l}\text { Mekongga+ } \\
\text { biorasional }\end{array}$ & $45,05 \mathrm{a}$ & $59,10 \mathrm{a}$ & $67,60 \mathrm{bc}$ & $70,10 \mathrm{a}$ & 15,80 a $24,10 \mathrm{ab}$ & 26,75 a 26,75 a \\
\hline Inpari 14+ biorasional & $44,40 \mathrm{ab}$ & $59,45 \mathrm{a}$ & & $72,95 \mathrm{a}$ & $24,70 \mathrm{ab}$ & 28,25 a 28,80 a \\
\hline Inpari $14+$ tanpa biorasional & $44,15 \mathrm{ab}$ & $59,00 \mathrm{a}$ & $70,15 \mathrm{~b}$ & $70,75 \mathrm{a}$ & $17,70 \mathrm{a}$ & 27,15 a 27,85 a \\
\hline Sintanur+ biorasional & $38,60 \mathrm{bc}$ & $54,55 \mathrm{~b}$ & $83,65 \mathrm{a}$ & $84,95 \mathrm{a}$ & $16,10 \mathrm{a}$ & 26,85 a 27,00 a \\
\hline Sintanur+ tanpa biorasional & $31,45 \mathrm{c}$ & $51,00 \mathrm{~b}$ & $82,60 \mathrm{a}$ & $83,10 \mathrm{a}$ & $12,80 \mathrm{a}$ & 26,85 a 26,85 a \\
\hline
\end{tabular}

Keterangan: Angka yang diikuti huruf yang sama pada kolom yang sama tidak berbeda nyata pada uji DMRT pada taraf $5 \%$.

\section{Intensitas Serangan Hawar Daun Bakteri}

Intensitas serangan HDB pada tanaman padi terlihat berpengaruh mulai umur 28 HST. Secara umum, aplikasi pestisida biorasional dapat menurunkan intensitas serangan penyakit HDB. Perlakuan varietas Sintanur dengan aplikasi pestisida biorasional menunjukkan persentase intensitas serangan HDB paling rendah (Tabel 2). Semua varietas tanaman diberikan pestisida biorasional memiliki intensitas serangan HDB yang lebih rendah. Hasil penelitian yang dilakukan di rumah kaca menunjukkan bahwa penyakit padi seperti hawar pelepah daun dapat dikendalikan oleh beberapa isolat bakteri dari kelompok Bacillus firmus, Burkholderia sp., dan Serratia marcescens yaitu dengan cara menghasilkan enzim-enzim dan senyawa metabolit yang berguna untuk menghambat perkembangan Xanthomonas oryzae pv oryzae sebagai penyebab HDB (Suryadi dkk., 2014). Aplikasi di lapangan menunjukkan bahwa pestisida biorasional yang mengandung mikroba Bacillus firmus, Burkholderia, dan Serratia marcescens dapat menurunkan intensitas serangan HDB dari $20 \%$ menjadi $0,71 \%$ (Nurawan dan Sunandar, 2015). Hasil penelitian Serdani dkk. (2018) melaporkan bahwa Burkholderia sp menjadi salah satu bakteri selain dari Bacillus cereus dan Enterobacter sp yang secara in vitro berpotensi dapat menekan X. oryzae pv. oryzae.

Tabel 2. Rata-rata Intensitas Serangan HDB Tanaman Padi

\begin{tabular}{lcccc}
\hline \multirow{2}{*}{ Perlakuan } & \multicolumn{4}{c}{ Intensitas serangan HBD (\%) } \\
\cline { 2 - 5 } & $14 \mathrm{HST}$ & $28 \mathrm{HST}$ & $42 \mathrm{HST}$ & $56 \mathrm{HST}$ \\
\hline Mekongga+ biorasional & $1,00 \mathrm{a}$ & $5,00 \mathrm{ab}$ & $6,00 \mathrm{ab}$ & $7,00 \mathrm{ab}$ \\
Mekongga+ tanpa biorasional & $3,00 \mathrm{a}$ & $7,00 \mathrm{a}$ & $9,00 \mathrm{ab}$ & $10,00 \mathrm{a}$ \\
Inpari 14+ biorasional & $3,00 \mathrm{a}$ & $10,00 \mathrm{a}$ & $9,00 \mathrm{ab}$ & $6,00 \mathrm{ab}$ \\
Inpari 14+ tanpa biorasional & $7,00 \mathrm{a}$ & $12,00 \mathrm{a}$ & $12,00 \mathrm{a}$ & $12,00 \mathrm{a}$ \\
Sintanur+ biorasional & $8,00 \mathrm{a}$ & $1,00 \mathrm{~b}$ & $0,00 \mathrm{c}$ & $0,00 \mathrm{c}$ \\
Sintanur+ tanpa biorasional & $9,00 \mathrm{a}$ & $4,00 \mathrm{ab}$ & $3,00 \mathrm{bc}$ & $3,00 \mathrm{bc}$ \\
\hline
\end{tabular}

Keterangan : Angka yang diikuti huruf yang sama pada kolom yang sama tidak berbeda nyata pada uji DMRT pada taraf $5 \%$

\section{Produktivitas}

Secara umum, aplikasi biorasional pada setiap varietas padi menghasilkan produktivitas lebih tinggi dibandingkan tanpa biorasional (Tabel 3). Menurut Nurawan dan Sunandar (2015) hasil ubinan gabah kering 
panen (GKP) padi pada perlakuan pemberian biorasional menghasilkan produktivitas paling tinggi dibandingkan penggunaan varietas tahan seperti Inpari HDB dan kontrol.

Varietas Sintanur dengan aplikasi pestisida biorasional memberikan nilai produktivitas lebih tinggi (Tabel 3). Hal tersebut didukung juga dengan tingkat intensitas serangan HDB 0\% terutama pada fase generatif. Tanaman yang sehat akan menunjang pertumbuhan dan perkembangan tanaman sehingga hasilnya pun optimal. Hasil penelitian Resti dkk. (2020) menunjukkan bahwa Bacillus sp dan Serratia marcescens merupakan bakteri endofit yang mampu mengendalikan hawar daun bakteri dan mendorong pertumbuhan bibit dan tanaman padi.

Tabel 3. Rata-rata Produktivitas Tanaman Padi

\begin{tabular}{lc}
\hline Perlakuan & Produktivitas $\left(\right.$ ton $\left.^{-1}\right)$ \\
\hline Mekongga+ biorasional & $6,78 \mathrm{a}$ \\
Mekongga+ tanpa biorasional & $5,56 \mathrm{ab}$ \\
Inpari 14+ biorasional & $6,78 \mathrm{a}$ \\
Inpari 14+ tanpa biorasional & $6,72 \mathrm{a}$ \\
Sintanur+ biorasional & $6,81 \mathrm{a}$ \\
Sintanur+ tanpa biorasional & $5,03 \mathrm{~b}$ \\
\hline Keterangan : Angka yang diikuti huruf yang sama pada kolom yang sama tidak berbeda nyata pada uji DMRT \\
$\quad$ pada taraf 5\%
\end{tabular}

Analisis Usahatani

Pendapatan dan nilai R/C rasio tertinggi diperoleh pada perlakuan varietas sintanur dengan aplikasi pestisida biorasional dengan nilai masing-masing sebesar Rp 17.462 .500 dan 2,79 (Tabel 4). Salah satu faktor yang menyebabkan lebih tingginya pendapatan dan nilai $\mathrm{R} / \mathrm{C}$ rasio pada perlakuan tersebut adalah produktivitasnya yang lebih tinggi dibandingkan dengan perlakuan lainnya.

Tabel 4. Penerimaan Total, Biaya Produksi Total, Pendapatan, dan R/C Rasio Usahatani Padi

\begin{tabular}{lcccc}
\hline Perlakuan & $\begin{array}{c}\text { Penerimaan total } \\
(\mathrm{Rp})\end{array}$ & $\begin{array}{c}\text { Biaya Produksi } \\
\text { total }(\mathrm{Rp})\end{array}$ & $\begin{array}{c}\text { Pendapatan } \\
(\mathrm{Rp})\end{array}$ & $\begin{array}{c}\mathrm{R} / \mathrm{C} \\
\text { rasio }\end{array}$ \\
\hline Mekongga+ biorasional & 27.120 .000 & 9.777 .500 & 17.342 .500 & 2,77 \\
Mekongga+ tanpa biorasional & 22.240 .000 & 10.722 .500 & 11.517 .500 & 2,07 \\
Inpari 14+ biorasional & 27.120 .000 & 9.777 .500 & 17.342 .500 & 2,77 \\
Inpari 14+ tanpa biorasional & 26.880 .000 & 10.722 .500 & 16.157 .500 & 2,51 \\
Sintanur+ biorasional & 27.240 .000 & 9.777 .500 & 17.462 .500 & 2,79 \\
Sintanur+ tanpa biorasional & 20.120 .000 & 10.722 .500 & 9.397 .500 & 1,88 \\
\hline
\end{tabular}

\section{KESIMPULAN}

Aplikasi pestisida biorasional dapat menurunkan intensitas serangan penyakit HDB pada tanaman padi. Varietas Sintanur dengan aplikasi pestisida biorasional menghasilkan produktivitas dan R/C rasio yang lebih tinggi yaitu dengan nilai masing-masing 6,81 ton ha-1 dan 2,79 .

\section{DAFTAR PUSTAKA}

Agustiansyah, Ilyas, S., Sudarsono, \& Machmud, M. (2013). Karakterisasi rizobakteri yang berpotensi dan meningkatkan pertumbuhan tanaman padi. J. HPT Tropika, 13(1), $42-51$. https://doi.org/https://doi.org/10.23960/ j.hptt.11342-51.

IRRI. (2013). Standard Evaluation System for Rice. International Rice Research Instiitute (5th ed.). Manila: IRRI. http://www.clrri.org/ver2/uploads/ SES_5th_edition.pdf.

Khoa, N. Đ., Giàu, N. Đ. N., \& Tuấn, T. Q. (2016). Effects of Serratia nematodiphila CT-78 on rice bacterial leaf blight caused by Xanthomonas oryzae pv. oryzae. Biological Control, 103, 1-10. https://doi.org/10.1016/j.biocontrol. 2016.07.010.

Nurawan, A., \& Sunandar, N. (2015). Kajian Penggunaan Biorasional Untuk Mengendalikan Hawar Daun Bakteri (HDB) Padi. In Prosiding Seminar Nasional Pengendaian Penyakit pada Tanaman Pertanian Ramah Lingkungan (pp. 48-54). Yogyakarta: Perhimpunan Fitopatologi Indonesia.

Putra, C., \& Giyanto, G. (2014). Kompatibilitas Bacillus spp. dan aktinomiset sebagai agens hayati Xanthomonas oryzae pv. oryzae dan pemacu pertumbuhan padi. Jurnal Fitopatologi Indonesia, 10(5), 160-169. https://doi.org/10.14692/ jfi.10.5.160. 
Resti, Z., Liswari, Y., \& Martinius. (2020). Endophytic bacterial consortia as biological control of bacterial leaf blight and plant growth promoter of rice (Oryza sativa L.). Journal of Applied Agricultural Science and Technology, 4(2), 134-145. https://doi.org/doi.org/10.32530/jaast.v4i2.146.

Serdani, A. D., Aini, L. Q., \& Abdul Latief Abadi. (2018). Isolasi dan identifikasi bakteri endofit dari tanaman padi (Oryza sativa) sebagai pengendali penakit hawar daun bakteri akibat Xanthomonas oryzae pv. oryzae. Viabel Pertanian, 12(1), 18-26. https://doi.org/https://doi.org/10.35457/viabel.v12i1.422.

Sudir, Nuryanto, B., \& Kadir, T. S. (2012). Epidemiologi, patotipe, dan strategi pengendalian penyakit hawar daun bakteri pada tanaman padi. Iptek Tanaman Pangan, 7(2), 79-87. http://repository.pertanian.go.id/handle/ 123456789/4322.

Suryadi, Y., Susilowati, D. N., Lestari, P., Priyatno, T. P., Samudra, I. M., Hikmawati, N., \& Mubarik, N. R. (2014). Characterization of bacterial isolates producing chitinase and glucanase for biocontrol of plant fungal pathogens. Journal of Agricultural Technology, 10(4), 983-999. http://www.ijat-aatsea.com.

Wahyudi, A. T., Meliah, S., \& Nawangsih, A. A. (2011). Xanthomonas oryzae pv. oryzae bakteri penyebab hawar daun pada padi : isolasi, karakteristik, dan telaah mutagenesis dengan transpososn. Makara, Sains, 15(1), 89-96. https://doi.org/https://doi.org/10.7454/mss.v15i1.885.

Zuraidah. (2013). Pengujian beberapa bakteri penghambat pertumbuhan Xanthomonas oryzae pv. oryzae pada tanaman padi. Jurnal Ilmiah Pendidikan Biologi, 5(1), 18-24. https://doi.org/https://doi.org/10.1234/jbe.v5i1.962. 